\title{
Effect of Phyto-Components of Allium Sativum and Syzyginum Aromaticum On The Performance And Biochemical Indices In Grower Broiler Chickens
}

\author{
*Garba, M.H. ${ }^{1}$, Ampitan, T.A. ${ }^{2}$, ,Tawakaltu, A-A4., \\ Nasir, S. ${ }^{1}$ Sabi'u, M.D'., Promise, O.A ${ }^{3}$. \\ ${ }^{1}$ Department of Biochemistry, \\ Federal University Dutse, \\ Jigawa State, Nigeria \\ ${ }^{2}$ Department of Forestry Technology, \\ Federal College of Wildlife Management, \\ Forestry Research Institute of Nigeria, \\ New Bussa, Niger State \\ ${ }^{3}$ Department of Animal Health and Production Technology, \\ Federal College of Wildlife Management, \\ Forestry Research Institute of Nigeria, \\ New Bussa, Niger State \\ ${ }^{4}$ Department of Biochemistry, \\ Federal University of Technology, Minna, \\ Niger State, Nigeria
}

Email:mharunagarba@gmail.com

\begin{abstract}
The potentials of Allium sativum and Syzyginum aromaticum on the performance and immunocompetence of grower broiler chickens was focused in this study. A total of one hundred and five (105) day old broiler chicks(Anak breed) were used in the study. Broiler starter diet was used to managed the birds until they attained five weeks of age. Thereafter, they were randomly allotted to seven treatments of 15 birds of three replicate each. To the treatments T1- T5: 0, 5, 10, 15, $20 \mathrm{~g} \mathrm{Kg-1}$ garlic-clove blend was supplemented, while $\quad 5 g \mathrm{Kg}^{-1}$ garlic alone (T6) and $2 \mathrm{~g} \mathrm{Kg}^{-1}$ clove alone (T7) were supplemented to the diets. Water, and supplemented feed were offered ad libitum. The duration of the experiment lasted to five weeks. Phytochemical analysis of the two spices revealed the presence of Alkaloids, flavonoids, saponins, steroids, phenols, terpenoids, anthraquinones and tannins, while, quantitative phytochemical screening showed high amount of Alkaloids (7.20 \pm $0.05 \mathrm{mg} / 100 \mathrm{~g})$, tannins $(4.80 \pm 0.03 \mathrm{mg} / 100 \mathrm{~g})$, saponins $(4.30 \pm 0.02 \mathrm{mg} / 100 \mathrm{~g})$, flavonoids $(2.18 \pm$ $0.03)$, and anthraquinones $(1.40 \pm 0.03 \mathrm{mg} / 100 \mathrm{~g})$. The proximate analysis of Syzyginum aromaticum also revealed high amount of Carbohydrates (oligosaccharides) (52.2 \pm 0.02$)$, fibre (20.00 $\pm 0.1)$, fats $(12.1 \pm 0.45)$ and ash $(5.2 \pm 0.01)$. The Feed Conversion Ratio (FCR) in all the treatments was comparable to the control and better in T2, T5, T6 and T7. There was no significant difference ( $P$ $\leq$ 0.05) in the serum Blood Urea Nitrogen (BUN) and serum Glutamate Oxalate Transaminase (SGOT) between the treatments and the control group. The serum total protein and the serum
\end{abstract}


albumin in the treated groups were not significantly different $((P \leq 0.05)$ while the serum globulin differ $(P \leq 0.05)$ between the treatments and the control groups. The performance characteristics and serum biochemical indices displayed by the experimental birds clearly showed the potency of these spices in improving the immuno-competence of the experimental birds.

Keywords: Allium sativum, Broiler finisher, Immuno-competence, Performance, Supplementation, Syzyginum aromaticum

\section{INTRODUCTION}

During a meeting with vice-chancellors of universities on the University-based poultry revival programme that was hosted by the governor of the Central Bank of Nigeria (CBN) in Abuja, in July, 2019, He stated that, with a current net worth of N1.6 trillion, the poultry sub-sector is the most commercialized of all Nigeria's agricultural sub-sectors. This, subsector according to him, contributes about Twenty five percent $(25 \%)$ of agricultural Gross Domestic Product (GDP) to the Nigerian economy. The CBN stock assessment put the population of chickens to about 165 million, from which approximately 650,000 metric tonnes and 300,00MT of eggs and meat are produced altogether. He stated that, to meet the demand of about 790,000MT and 1,500,000MT for eggs and meat, over 200 million birds need produced. It was pointed out that, over 1.2 million MT of poultry meat is smuggled into Nigeria from Benin Republic due to this supply gap, a situation that cannot be tolerated and must be reversed through improved production methods. (The Cable, P 8, 2019).

The CBN also projected that, with the expected Nigeria's population of 400 million by 2050, of which 80 million o the number will live in the cities, significant increase in the demand for poultry products is expected. However, despite the projection, consumption of chicken as a protein source is still very low per capita at $2.5 \mathrm{~kg}$ in Nigeria in comparisonto to Brazil and South Africa at $30 \mathrm{~kg}$ and $40 \mathrm{~kg}$ respectively. More so, when the per capita consumption of eggs in Nigeria is 60 eggs per annum, most advanced countries consume 250 to 300 eggs per annum. (The Cable, Page 8, 2019).

In Nigeria, with the estimated poultry population of 24.3 million in the southwest, 22.6 million in the central zone, 17.8 milion birds in the northwest, 16.0 million in the southeast and 15.8 million in the northeast efforts must be geared towards increase production in some regions (Dayo et al., 2009).

Broilers make up $70 \%$ of the chicken population in Nigeria, while layers account for $30 \%$. (Babbangonablog, 2020). Broilers are of strains that have been bred to be very fast growing in order to gain weight quickly (Compassion in World Farming, 2013).

Food security is said to be achieved when people produce or have access to sufficient high quality and quantity of affordable food. Poultry production is the most efficient and costeffective way to increase the availability of high-protein food has been generally acknowledged (FAO, 2018).

Spice herbs have been used therapeutically to improve health and wellbeing of animals, mostly for prophylactic purposes and to improve growth and feed utilisation (Simon, 2005). This in addition to being important part of human diet, spices have also been used for centuries in traditional medicine (Rivlin, 2001). Herbs and spices are known for their preservative (Neilsen and Rios, 2000), antioxidative (Shobana and Naidu, 2000), and antimicrobial (Salie et al., 1996) roles in addition to boosting flavor. 
Puvača et al. (2013) pointed out that; garlic is one of the most traditionally used plants as a medicinal herb. have been shown to exhibit: Anti-atherosclerotic, antimicrobial, hypolipidemic, antithrombotic, antihypertensive, antidiabetic effects have been shown to be exhibited by garlic preparations and extracts (Mansoub, 2011). Allicin have been found $t$ be the main active components in garlic (Rahmatnejad and Roshanfekr, 2009). Stanaćev et al. (2010) stated that; feeding garlic as a supplement improved broiler growth and FCR, and decreased mortality rate. Heightened broilers performance and carcass traits may also be achieved by including levels of $1.5,3$ and $4.5 \%$ which caused a significant reduction in poultry serum, liver and skin cholesterol content (Puvača et al., 2015).

Cloves have been reported to originate from southern Philippines and the Islands of Moluccas in Indonesia. The presence of eugenol and beta caryophyllene in cloves, made it a popular local anesthetic of choice in dentistry due toits analgestic effect. Its antibacterial and anti-inflammatory properties are effectively used in drugs formulation and dental fillings in dentistry. It also promotes proper flow of nutrients and oxygen throughout the body by increasing blood circulation, thus, enhancing the body metabolism. They have also been found to help in maintaining cardiovascular health through inhibiting the clotting of blood. Due to its aphrodisiac and stimulant properties, clove have been found to serves as an excellent stress reliever. By removing mental exhaustion and inducing sleep, It also aids in treating depression and anxiety and alleviating insomnia effectively $(\mathrm{Okwu}, 2001)$.

The main focus of this research work was investigating the effect of inclusion of clovegarlic blend in the diet of grower broiler chickens on performance and serum biochemical indices, in the experimental animals.

\section{MATERIALS AND METHODS}

\section{Methods}

\section{Experimental Site:}

The experimental station (New Bussa) sits at $9^{\circ} 53^{\prime} \mathrm{N}, 9^{9} 83^{\circ} \mathrm{N}$ and $4{ }^{\circ} 31^{\prime} \mathrm{E}, 4.517^{\circ} \mathrm{E}$ (NIPOST Archives, 2009). The research work was carried between the Months of May to July (early part of rainy season)

The garlic and the cloves were purchased from the New Bussa market. They were washed and dried at room temperature and then separately packaged in a polythene bag until required for use.

\section{Preparation of the garlic-clove powder}

Mortal and pestle were used to pulverize the dried clove (Syzygium aromaticum (L.)) into a powdered sample. It was sieved through a $0.5 \mathrm{~mm}$ pore-sized sieve. While the garlic (Allium sativum $\mathrm{L}$ ) was roasted to temperature of $60^{\circ} \mathrm{C}$ in a microwave oven and then pulverised into a powdered form and packaged in a polythene bag and kept until required for use.

\section{Formulation of the clove-garlic blend}

Based on the NRC (1994) prescription guide line, the pulverised form of the clove and the garlic were combined in the ratio $30: 70 \%(\mathrm{w} / \mathrm{w})$ and packaged as a single formulation in a polythene bag. 


\section{Birds and husbandry}

A total of One hundred and five (105) day-old broiler chicks were purchased from P.J speciality (a reputed poultry and poultry products distributor in New Bussa).

The chicks were managed on broiler starter diet (feed) until they attain five weeks of age. They were then, randomly distributed into seven treatments of 15 birds of three replicates containing five birds. No supplementation of clove-garlic blend in the diet (T1, control), dietary supplementation of $5 \mathrm{~g} \mathrm{kg-1}$ garlic-clove blend, (T2), dietary supplementation of $10 \mathrm{~g}$ $\mathrm{kg}^{-1}$ garlic-clove blend (T3), dietary supplementation of $15 \mathrm{~g} \mathrm{Kg}^{-1}$ garlic-clove blend (T4), dietary supplementation of $20 \mathrm{~g} \mathrm{~kg}^{-1}$ garlic-clove blend (T5), dietary supplementation of $5 \mathrm{~g}$ $\mathrm{kg}^{-1}$ garlic alone (T6) and dietary supplementation of $2 \mathrm{~g} \mathrm{~kg}^{-1}$ clove alone (T7). Birds were exposed to a lighting regimen of 17 hours of (natural and artificial) light in $24 \mathrm{~h}$. Water, and feed were offered ad libitum. The experiment from the grower to finisher level lasted for six weeks.

The experimental diets were formulated at the Federal College of Wildlife Management (FCWM). farm feed mill. A typical broiler starter/finisher diet, were formulated based on the National Research Council (NRC), (1994) requirements

\section{Performance characteristics measurements}

Birds were allotted into treatments and each treatment assigned into three replicates. The initial weight of the birds was measured. Data on the feed intake and weight gain was collected weekly, in the course of experiment.

$$
\begin{aligned}
& \text { Feed intake I }(\mathbf{g}) \text { = Feed supplied - Feed left-over } \\
& \text { Weight gain }(\mathbf{g})=\text { Final weight }- \text { Initial weight } \\
& \text { Feed Conversion Ratio (FCR) }=\frac{\text { Total feed consumption }}{\text { Total body weight gain }}
\end{aligned}
$$

\section{Measurements of Biochemical indices}

These parameters were determined based on the methods of Tietz (1995) and Reitman and Frankel, (1957) while Gornall et al. (1949) method was for proteins

\section{Measurements of Phytochemical components}

The methods described by Trease and Evans, (2002) and Sofowora, (1982) were employed to qualitatively determined the phytochemical components.

\section{Determination of proximate compositions}

The AOAC, (2000) methods of analysis was employed in this aspect

\section{Statistical analyses}

All data were subjected to analysis of variance (ANOVA) as Completely Randomized Block Design according to the SAS., 2013. SAS user's guide statistics. Software Version 9.4.SAS Inst Institute, Inc., Cary, NC, USA.

\section{RESULTS}

The pharmacological efficacies of most plants or plant parts is a function of the presence of some phytochemicals contained therein. These phytochemicals are known to be pharmacologically active against varieties of pathogenic organisms ranging from parasites, bacteria, fungi and viruses; some were even found to possess anticancer, neoplastic, anti- 
inflammatory and anti-necrotic properties. Like any other plant species, Allium sativum (garlic) has been found to contain such phytochemicals as shown in Table 1

Table 1: Phytochemical composition of Allium sativum aqueous and ethanol extracts

\begin{tabular}{lcc}
\hline \multicolumn{1}{c}{ Phytochemical } & Aqueous & Ethanol \\
\hline Alkaloids & + & + \\
Flavonoids & + & + \\
Glycosides & + & + \\
Reducing sugar & + & + \\
Saponins & + & + \\
Steroids & + & + \\
Phenols & + & + \\
Terpenoids & + & + \\
Anthraquinons & + & + \\
Tannin & & + \\
\hline
\end{tabular}

Plants phytochemical components whenever measured quantitatively were found to be in varying concentrations. The extent and amount to which the phyto-components exist in a particular plant or plant part will to a great extent, determine the pharmaco-activities of the plant under consideration. The solvent used in the extraction (depending on its polarity) will also be a factor that will determine the yield of the extract as portrayed in Table 4.2.

Table 2: Weight of Phytochemical components from Alium sativum aqueous and ethanol extracts

\begin{tabular}{lc}
\hline Phytochemical & Weight in $\mathbf{~} \mathbf{1 0 0 g}$ \\
\hline Alkaloids & $7.20 \pm 0.05$ \\
Flavonoids & $2.18 \pm 0.03$ \\
Glycosides & $0.05 \pm 0.00$ \\
Saponins & $4.30 \pm 0.02$ \\
Steroids & $0.05 \pm 0.00$ \\
Phenols & $0.80 \pm 0.00$ \\
Terpenoids & $0.40 \pm 0.01$ \\
Anthraquinons & $1.40 \pm 0.03$ \\
Tannin & $4.80 \pm 0.03$
\end{tabular}

The values are the mean of triplicate measurements \pm Standard deviation (SD).

The pharmacological efficacies of most plants or plant parts is a function of the presence of some phytochemicals contained therein. These phytochemicals are known to be 
pharmacologically active against various pathogenic organisms ranging from parasites, bacteria, fungi and viruses; some were even found to possess anticancer, neoplastic, antiinflammatory and anti-necrotic properties. Like any other plant species, Allium sativum (garlic) has been found to contain such phytochemicals as shown in Table 3

Table 3: Phytochemical composition of Syzyginum aromaticum ethanol extract

\begin{tabular}{lc}
\hline Phytochemical & Detection status \\
\hline Carbohydrates & + \\
Proteins & + \\
Terpenoids & + \\
Steroids & + \\
Glycosides & + \\
Alkaloids & + \\
Tannins & + \\
Phenolics & + \\
\hline
\end{tabular}

From the nutrition standpoint, nutritional potency of most plants and plant products is assessed through the determination of its proximate chemical composition. This qualitative measurement provide a first- hand information on the macro and micro nutrients composition of the plant part or product and by extrapolation, the nutritive value of the plant both as food or nutraceutical. The quantitative measurement conducted on Syzyginum aromaticum revealed its proximate composition as presented in Table 4

Table 4: Proximate Composition of Dried Syzyginum aromaticum

\begin{tabular}{ll}
\hline Chemical compund & Concentration determined \\
\hline Protein & $1.2 \pm 0.02$ \\
Carbohydrates & $52.2 \pm 0.02$ \\
Fats & $12.1 \pm 0.45$ \\
Fibre & $20.00 \pm 0.1$ \\
Moisture & $10.00 \pm 0.06$ \\
Ash & Group.
\end{tabular}

The values are the mean of triplicate measurements \pm Standard deviation (SD).

The composition of the experimental diet is such that, it ensures the presence of all the nutrients required for the fast and healthy growth of the experimental birds. As indicated in Table 4.5, Major sources of energy, growth and boosting of the organism's immunity have been incorporated to guaranty the achievement of not just the short duration to attain table size, but also confer on the products from such bird, right and enough composition of nutrients both qualitatively and quantitatively. 
Table 5: Composition of Experimental Diet at Finisher Phase

\begin{tabular}{llllllll}
\hline \multicolumn{1}{c}{$\begin{array}{c}\text { Ingredients } \\
(\mathrm{Kg})\end{array}$} & $\mathrm{T}_{1}$ & $\mathrm{~T}_{2}$ & $\mathrm{~T}_{3}$ & $\mathrm{~T}_{4}$ & $\mathrm{~T}_{5}$ & $\mathrm{~T}_{6}$ & $\mathrm{~T}_{7}$ \\
\hline Maize & 50.2 & 50.2 & 50.2 & 50.2 & 50.2 & 50.2 & 50.2 \\
Soya beans & 20 & 20 & 20 & 20 & 20 & 20 & 20 \\
Fish meal & 10 & 10 & 10 & 10 & 10 & 10 & 10 \\
GNC & 6.0 & 6.0 & 6.0 & 6.0 & 6.0 & 6.0 & 6.0 \\
Wheat offal & 9.7 & 9.7 & 9.7 & 9.7 & 9.7 & 9.7 & 9.7 \\
Bone meal & 3.0 & 3.0 & 3.0 & 3.0 & 3.0 & 3.0 & 3.0 \\
Methionine & 0.25 & 0.25 & 0.25 & 0.25 & 0.25 & 0.25 & 0.25 \\
Lysine & 0.25 & 0.25 & 0.25 & 0.25 & 0.25 & 0.25 & 0.25 \\
Vitamins & 0.25 & 0.25 & 0.25 & 0.25 & 0.25 & 0.25 & 0.25 \\
premix & 0.25 & 0.25 & 0.25 & 0.25 & 0.25 & 0.25 & 0.25 \\
Salt & 0.05 & 0.05 & 0.05 & 0.05 & 0.05 & 0.05 & 0.05 \\
$\begin{array}{l}\text { Powder } \\
\text { coccidiostat }\end{array}$ & & & & & & & \\
Growth & 0.05 & 0.05 & 0.05 & 0.05 & 0.05 & 0.05 & 0.05 \\
enhancer & & & & & & & \\
Total & $\mathbf{1 0 0 . 0 0}$ & $\mathbf{1 0 0 . 0 0}$ & $\mathbf{1 0 0 . 0 0}$ & $\mathbf{1 0 0 . 0 0}$ & $\mathbf{1 0 0 . 0 0}$ & $\mathbf{1 0 0 . 0 0}$ & $\mathbf{1 0 0 . 0 0}$ \\
$\begin{array}{l}\text { Garlic/clove } \\
\text { blend }\end{array}$ & 0.00 & 0.5 & 1.00 & 1.50 & 2.00 & 0.00 & 0.00 \\
Garlic alone & 0.00 & 0.00 & 0.00 & 0.00 & 0.00 & 0.50 & 0.00 \\
Clove alone & 0.00 & 0.00 & 0.00 & 0.00 & 0.00 & 0.00 & 0.20 \\
\hline
\end{tabular}

The quantity of feed supplied to the experimental birds on daily basis were compared with what is left at the end of the day and the difference was recorded for seven consecutive days as the average weekly feed consumption. As depicted in Table 6, there is a remarkable decrease in the amount of feed consumed as the experimental birds transits from the grower to the finisher stage. This phenomenon is quite an advantage when taken in the concept of the economy of production.

Table 6 Average weekly feed consumption in experimental bird's fed graded level of feed supplemented with different matrices of Allium sativum and Syzyginum aromaticum and also singly.

\begin{tabular}{llllll}
\hline Treatment & $\mathbf{W K}_{5}$ & $\mathbf{W K}_{6}$ & $\mathbf{W K}_{7}$ & $\mathbf{W K}_{8}$ & $\mathbf{W K}_{9}$ \\
\hline 1 & $249.04^{\mathrm{b}}$ & $414.10^{\mathrm{ab}}$ & $537.91^{\mathrm{a}}$ & $655.93^{\mathrm{b}}$ & $722.25^{\mathrm{de}}$ \\
2 & $284.28^{\mathrm{e}}$ & $428.67 \mathrm{~b}$ & $591.21^{\mathrm{b}}$ & $659.38^{\mathrm{b}}$ & $712.43^{\mathrm{cd}}$ \\
3 & $266.57^{\mathrm{cd}}$ & $420.79^{\mathrm{b}}$ & $591.50 \mathrm{~b}$ & $660.68 \mathrm{~b}$ & $697.43 \mathrm{c}$ \\
4 & $261.27^{\mathrm{c}}$ & $376.67^{\mathrm{ab}}$ & $524.10^{\mathrm{a}}$ & $601.42^{\mathrm{a}}$ & $631.29^{\mathrm{a}}$ \\
5 & $273.16^{\mathrm{d}}$ & $409.24^{\mathrm{ab}}$ & $606.43^{\mathrm{c}}$ & $709.66^{\mathrm{c}}$ & $736.80^{\mathrm{e}}$ \\
6 & $242.83^{\mathrm{a}}$ & $402.53^{\mathrm{ab}}$ & $539.57^{\mathrm{a}}$ & $718.31^{\mathrm{c}}$ & $663.78^{\mathrm{b}}$ \\
7 & $235.17^{\mathrm{a}}$ & $320.06^{\mathrm{a}}$ & $211.40^{\mathrm{d}}$ & $641.73^{\mathrm{a}}$ & $645.71^{\mathrm{b}}$ \\
SEM & & & & & 8.702 \\
\hline
\end{tabular}


Values on the same row with different superscripts are significantly different $(\mathrm{P} \leq 0.05)$

As a natural principle, animals tendency to gain increase in body size is dependent not solely, in the quantity of the feed supplied, but partly due to the quality of the nutrients it is composed of. The ability of the supplied diet to provide nutrient that support body immunity, enhance growth, guaranty the repair of the worn-out tissues, support the strength and development of the body skeletal and nervous systems and suppress the spread and proliferation of microbial pathogens are what qualifies feed as standard rather than just the quantity supplied. The growth pattern shown by Table 4.7 seems to be in tune with the afore mentioned attributes of a good feed/diet.

Table 7: Average weekly weight gain displayed by experimental birds fed diet supplemented with Allium sativum and Syzyginum aromaticum matrices and singly.

\begin{tabular}{ccccccccc}
\hline & $\mathbf{1}$ & $\mathbf{2}$ & $\mathbf{3}$ & $\mathbf{4}$ & $\mathbf{5}$ & $\mathbf{6}$ & $\mathbf{7}$ & SEM \\
\hline Age in wks & & & & & & & & \\
\hline Week5 & $347.93^{\mathrm{ab}}$ & $377.33^{\mathrm{b}}$ & $384.73^{\mathrm{b}}$ & $359.20 \mathrm{~b}^{\mathrm{c}}$ & $421.60^{\mathrm{c}}$ & $266.16^{\mathrm{ab}}$ & $336.37^{\mathrm{a}}$ & 6.89 \\
Week6 & $511.53^{\mathrm{abc}}$ & $334.86^{\mathrm{cd}}$ & $522.33^{\mathrm{bcd}}$ & $505.13^{\mathrm{abc}}$ & $580.00^{\mathrm{d}}$ & $466.53^{\mathrm{ab}}$ & $458.67^{\mathrm{a}}$ & 10.83 \\
Week7 & $783.27^{\mathrm{a}}$ & $868.13^{\mathrm{b}}$ & $765.13^{\mathrm{ab}}$ & $701.93^{\mathrm{a}}$ & $850.93^{\mathrm{b}}$ & $705.20^{\mathrm{a}}$ & $693.53^{\mathrm{a}}$ & 18.91 \\
Week8 & $1183.33^{\mathrm{bc}}$ & $1253.33^{\mathrm{c}}$ & $1133.33^{\mathrm{bc}}$ & $933.33^{\mathrm{a}}$ & $1174.33^{\mathrm{bc}}$ & $1080.00^{\mathrm{ab}}$ & $1066.66^{\mathrm{ab}}$ & $26.77^{2}$ \\
Week9 & $1493.33^{\mathrm{ab}}$ & $1580.00^{\mathrm{ab}}$ & $1466.6^{\mathrm{ab}}$ & $1346.60^{\mathrm{a}}$ & $1666.66^{\mathrm{b}}$ & $1433.33^{\mathrm{ab}}$ & $1413.33^{\mathrm{a}}$ & 32.04
\end{tabular}

Values on the same row with different superscripts are significantly different ( $\mathrm{P} \leq 0.05)$

The ability of animals to breakdown and efficiently convert the food supplied into a functional protein is usually measured to determine to what extent the component of the feed supplied contributed to the meat formation in the animal in question and this has been pictured out in Table 8

Table 8: Performance of broiler finisher chicken fed diet supplemented with Syzyginum aromaticum and Allium sativum

\begin{tabular}{|c|c|c|c|c|c|c|c|c|}
\hline Parameters & $\mathrm{T}_{1}$ & $\mathrm{~T}_{2}$ & $\mathrm{~T}_{3}$ & $\mathrm{~T}_{4}$ & $\mathrm{~T}_{5}$ & $\mathrm{~T}_{6}$ & $\mathrm{~T}_{7}$ & SEM \\
\hline $\begin{array}{l}\text { Mean initial body } \\
\text { weight }(\mathrm{g})\end{array}$ & $347.93^{a b}$ & $377.33^{b}$ & $384.7^{b}$ & $359.20^{\mathrm{ab}}$ & $421.60^{c}$ & $266.16^{\mathrm{ab}}$ & $336.37 a$ & 6.89 \\
\hline $\begin{array}{l}\text { Mean final body } \\
\text { weight }(\mathrm{g})\end{array}$ & $1493.33^{a}$ & $1580.00^{a b}$ & $1466.6^{\mathrm{ab}}$ & $1346.6^{a}$ & $1666.66^{b}$ & $1433.33^{a b}$ & $1413.33^{a}$ & 32.04 \\
\hline $\begin{array}{l}\text { Mean body weight } \\
\text { gain }(\mathrm{g})\end{array}$ & 1145.40 & 1202.67 & 1081.87 & 987.40 & 1245.06 & 1167.17 & 1147.17 & 0.00 \\
\hline $\begin{array}{l}\text { Mean feed } \\
\text { consumed }\end{array}$ & $722.25^{\text {de }}$ & $712.43^{\mathrm{cd}}$ & $697.43^{c}$ & $631.29 a$ & $736.80^{\mathrm{e}}$ & $663.78^{b}$ & $645.71^{\mathrm{ab}}$ & 8.702 \\
\hline $\begin{array}{l}\text { Feed conversion } \\
\text { ratio }(\mathrm{FCR})\end{array}$ & 0.63 & 0.60 & 0.64 & 0.64 & 0.59 & 0.57 & 0.56 & 0.00 \\
\hline
\end{tabular}

Values on the same row with different superscripts are significantly different $(\mathrm{P} \leq 0.05)$

$\mathrm{T} 1-\mathrm{T} 7=$ Treatments $1-7, \mathrm{SEM}=$ Standard Error of Mean

Performance characteristics measurements

Birds were allotted into treatments and each treatment assigned into three replicates. The initial and the final weights of the birds were taken. Data on the feed intake and weight gain was recorded at the end of the experiment. 


\section{Biochemical indices determined}

Exposure to microbial infection and/or administration of some diets, chemicals or phytochemicals subject some organs or tissues in animals to either inflammatory or necrotic lesions. Biochemical analysis of some biomarkers reveal to a reasonable extent, the dietary contribution or pathological effect that such diet or phyto-components contributed to, in the experimental birds. Table 9 shows in detail how the supplementation of the administered feed brings about variation in the serum biochemical composition across different treatment. When viewed and analysed individually, high or low level of each parameter will clearly reveal the safety level or pathology of the organ or tissue concerned.

Table 9: Serum biochemical indices in experimental birds fed diets supplemented with

\begin{tabular}{|c|c|c|c|c|c|c|c|c|}
\hline \multirow{2}{*}{$\begin{array}{l}\text { Biochemical } \\
\text { indices }\end{array}$} & \multicolumn{8}{|c|}{ Treatment } \\
\hline & 1 & 2 & 3 & 4 & 5 & 6 & 7 & SEM \\
\hline UREA & $7.670^{\mathrm{b}}$ & $6.62^{a b}$ & $6.61^{\mathrm{ab}}$ & $5.23^{a}$ & $7.87 \mathrm{~b}$ & $7.60^{\mathrm{b}}$ & $6.97 \mathrm{~b}$ & 0.23 \\
\hline SGOT & $64.10^{\mathrm{e}}$ & $56.90^{c}$ & $49.75^{a}$ & $51.70^{\mathrm{b}}$ & $58.40^{\mathrm{cd}}$ & $59.45^{d}$ & $67.50 \mathrm{e}$ & 1.32 \\
\hline SGPT & $31.15^{c}$ & $26.30^{b}$ & $13.25^{\mathrm{a}}$ & $14.70^{a}$ & $15.75^{a}$ & $34.05^{\mathrm{d}}$ & $13.25^{\mathrm{a}}$ & 1.88 \\
\hline Albumin & $2.400^{b}$ & $2.700^{d}$ & $2.200^{a}$ & $2.650^{d}$ & $2.650^{\mathrm{d}}$ & $2.250^{\mathrm{ab}}$ & $2.550^{\mathrm{cd}}$ & 0.05 \\
\hline Globulin & $1.850^{\mathrm{b}}$ & $1.250^{\mathrm{a}}$ & $2.350^{\mathrm{d}}$ & $2.300^{\mathrm{cd}}$ & $3.250 \mathrm{e}$ & $1.800^{\mathrm{b}}$ & $2.050^{b c}$ & 0.31 \\
\hline Total Protein & $4.250^{\mathrm{b}}$ & $3.950 \mathrm{a}$ & $4.20^{b}$ & $4.950 \mathrm{c}$ & $5.95^{c}$ & $4.050^{\mathrm{b}}$ & $4.600 c$ & 1.95 \\
\hline
\end{tabular}

Values on the same row with different superscripts are significantly different $(\mathrm{P} \leq 0.05)$

SGOT $=$ Serum glutamate oxalate transaminase, $\mathbf{S G P T}=$ Serum glutamate pyruvate transaminase

\section{DISCUSSION}

Supplementation of poultry feed with some natural supplements has been known to contribute both to the organoleptic scores of the feed and the provision of extra macro and micro nutrients required for healthy growth and performance of the birds (Muhammad and Idris, 2019). Considering the graded supplementation of grower broilers feed with both garlic/clove blend and seperately (Table 5), there was a significant increase $(P \leq 0.05)$ in the performance across all the groups fed with the supplemented diet compared with the control group (Table 8) except in group T3 and T4 that differ from the control T1, which could be attributed to either feed rejection induced by the level of supplementation or the genomes of some the birds in the groups (since the allocation is completely randomised).

Broad-spectrum of phytochemicals with a large number of bioactivities such as polysaccharides, terpenoids, essential oils phenolics, polyacetylenes and alkaloids are produced by plants (Bozkurt et al., 2013). As revealed in Tables 1, 2, 3 and 4, phytochemical analysis of the Allium sativum and Syzyginum aromaticum extracts showed the presence of these compounds which agrees with the findings of Nwadiaro et al. (2015). As reported by Aliero and Gumi (2012); Usman et al. (2014), the bulb and bud of garlic and clove contains 
higher concentration of alkaloids than their leaves Therefore, the high alkaloids concentration observed in this study is a result of using the bulb and the clove bud. Gupta et al. (2014) reported that, classes of compounds such as: Alkaloids, saponins, tannins, anthraquinones, and flavonoids are known to have curative activity against several pathogens. Flavonoids have been referred to as nature's biological response modifiers, due to their ability to modify the body's immune-response to invading pathogens (Nwadiaro et al., 2015).

Worthy of note is the presence of carbohydrate as a component of phytochemicals and as a proximate component of Syzyginum aromaticum in large quantity (Tables 3 and 4). AlSheraji, et al. (2013) reported that, some oligosaccharides such as: Inulin, arabinoxylooligosaccharides (AOS), fructo oligosaccharides(FOS), mannan-oligosaccharides (MOS), xylo-oligosaccharides (XOS), isomalto-oligosaccharides (IMOS), soy oligosaccharides (SOS), and pyrodextrins were found to be contained in A. sativum and Syzyginum aromaticum. These components were reported to possess some prebiotic properties as a result of being non-digestible feed components that promote the growth microbiota in guts (Bindels et al., 2015). The mechanism of action of these oligosaccharides is through selective activation of beneficial microbes in the intestinal system of the bird. The harmful pathogens are usually prevented from colonizing the intestinal tract by the increasing number of beneficial microbiota of the bird. Subsequently, the production of a wide variety of bacterions and other immuno-modulators able to stimulate macrophages to neutralize the pathogens is achieved by healthy hosts (Alloui et al., 2013). Moreover, the suppression of coccidial infection in chickens by prebiotics while keeping the marginal oocyst production that might serve as a source of live vaccine for uninfected chickens has been reported by Bozkurt et al. (2014).

Syzyginum aromaticum (Clove) also contains an essential oil made up of: 75 - 85\% eugenol, $15 \%$ eugenyl acetate and 51.2\% $\beta$ - caryophylline (Monika et al., 2014) whose derivatives has lots of biological benefits such as: Antimicrobial, Insecticidal, carcino-suprression, and antioxidant activities (Makun, 2018). Additionally, essential oil from clove has been shown to be more effective than eugenol in scavenging activity against 2,2- diphenyl- 1- picryl hydracyl (DPPH) radical at concentration, Butylated hydroxytoluene (BHT) and Butylated hydroxyanisole (BHA). It also acts as an iron chelator. The inhibitory activity of clove oil against lipid peroxidation determined using lipid peroxidation and linoleic acid emulsion system has been reported by Leopold et al.(2006).

Sulfur compounds such as: Ajoene, allyl polysulfides, vinyldithiins and the presence of Sallylcysteine has also been observed in garlic. These compounds has been established to remedy many ailments, including intestinal disorders, flatulence, worms, respiratory infections, skin diseases, wounds, and symptoms of aging (Rodrigo et al., 2015). As indicated by modern research, garlic helps to improve heart health in a number of different ways such as: Being Blood thinner (that helps to lower both high blood pressure and blood triglycerides) and anti-arthritic (Siegel et al., 2004). Tilli et al. (2003); Rodrigo et al. (2015) reported that, there is an association between an increased intake of garlic and a reduced risk of certain cancers (Schafer and Kaschula, 2014). Effectiveness of garlic at killing antibiotic-resistant bacteria, including MRSA (Schafer and Kaschula, 2014).

Summing up, from the wide ranges of the afore-mentioned medicinal and nutritional benefits of Allium sativum and Syzygium aromaticum, it suffice to state that, the very minimal mortality rate (just two birds) recorded in the course of the entire experimental period is 
quite justified. Despite the fact that, it is in T2, T5, T6 and T7 (Table 8) that a significant difference $(\mathrm{P} \leq 0.05)$ in body weight increase exist, it suffice to say that, robust and a steady state of health with very little mortality rate should be the ultimate dream of every farmer.

Assessing the biochemical indices (Table 9) in serum and organs of animals has been a valuable tools in determining the integrity and functionality of organs as well as risk assessment, pathological condition and general health status of the body. Feed supplied, a drug, extract/compound or supplement determines the deficiency/over expression in the activities of these enzyme biomarkers in serum and body tissues (Oluwatosin et al., 2015). Compromised liver activities brings about variation in the expression of transaminase enzymes especially the SGOT (AST) and SGPT (ALT) which to a certain extent can offer a quantitative measurement of the extent of hepatocellular damage. More so, valuable information relevant to the integrity of the hepatocyte are obtained from the SGPT activities than SGOT (Abu and Uchendu, 2010). However, in the present work marked increase in SGOT activities observed in T1 and T7 (Table 9) may have occurred as a result of the absence of garlic in these feed offered and hence limit the supply of the Ajoene and sulphurhidryl compounds which greatly contribute in relieving or overcoming stress induced by some toxic molecules present in the feed substance (Adeyemi et al., 2012).. The serum SGPT is cytosolic in origin, therefore, the non-significant change in the serum SGPT activities observed in T2, T3, T4, T5 and T7 (Table 9), following feeding with the experimental diet when compared with the T1 and T6 could be translated to mean that the presence of Syzyginum aromaticum as previously mentioned has helped to maintained the intergrity of the hepatocvtes. Probably the reason for the increase outflow observed in T1 and T6 demonstrated selective toxicity on transaminase since only the activity of SGPT was altered in the treatments $\mathrm{T} 1$ and $\mathrm{T} 6$.

Kidney function parameters help greatly in assessing the integrity of various parts of the nephrocytes (Singh et al., 2011). In this vein, Yakubu and Musa (2012) posited that, the level of creatinne, electrolytes, urea, and serum total protein could also provide a reliable insight regarding the influence of a supplement, drug or compound extract on the essential regions of the kidney. The observed constancy in the level of serum total proteins indicates that the supplementation with both Syzyginum aromaticum and A. satioum does not in any way impair with the normal function of the liver as a result of the administration of these supplements. It can be stated with a degree of certainty that, the supplements does not interfere with the balance in the order of synthesis and utilization of total protein, from the system of the experimental birds. In pathological conditions, such decrease could results into hydration with consequent effects on cellular homeostasis and resultant health status of the birds.

The observed steady level in urea concentration observed in all the treatments (Table 9) could be attributed to the absence of renal dysfunction as a result of supplementing the experimental diet. Eliciting any renal dysfunction by the supplemented diet would have led to excessive urea excretion from the kidney, or destruction of the urea cycle leading to a decrease urea production or impairment in the tubular excretory function of the kidney (Ogbu et al., 2011),

\section{REFERENCES}

Abu, A.H, Uchendu, C.N. (2010). Safety assessment of aqueous ethanolic extract of Hymenocardia acida stems bark in Wistar rats. Archives of Applied Science Research 2(5): 56-68. 
Adeyemi, O.S., Fambegbe, M, Daniyan, O.R., Nwajei, I. (2012). Yoyo Bitters, a polyherbal formulation influenced some biochemical parameters in Wistar rats. Journal of Basic Clinical Physiology and Pharmacology 23; (4): 135-8.

Aliero, A.A., Gumi, A.M. (2012): Studies on the germination, chemical composition and antimicrobialproperties of Cucumis metuliferus. Ann. Biol. Res. 3(8): 4059- 4064.

Alloui, M. N. . Szczurek, W., Swiatkiewicz, S. (2013). "The usefulness ' of prebiotics and probiotics in modern poultry nutrition": A review Annals of Animal Science, 13(1): 1732

Al-Sheraji, S. H. . Ismail, A Manap, M. Y.. Mustafa, S, Yusof, R. M., Hassan, F. A. (2013.). "Prebiotics as functional foods: a review," Journal of Functional Foods, 5(4): 1542-1553,

AOAC. Official methods of analysis. (2000) 17th Ed. Association of Official Analysis Chemists, Washington DC; Pp 56

Bindels, L. B. Delzenne, N. M. Cani, P. D. Walter, J. (2015). “Towards a more comprehensive concept for prebiotics, Nature Reviews Gastroenterology \& Hepatology, 12(5,) 303-310,

Bozkurt, M.. Aysul, N. Kuc K “.,ukyilmaz, Y. (2014). "Efficacy of feed preparations of an anticoccidial, multienzyme, prebiotic, probiotic, and herbal essential oil mixture in healthy and Eimeria spp.-infected broilers," Poultry Science, 93( 2): 389-399

Bozkurt, M.. Giannenas, I. Kuc “, ukyilmaz, K. Christaki, E and P. “' Florou-Paneri, (2013). "An update on approaches to controlling coccidia in poultry using botanical extracts," British Poultry Science, 54 (6):713-727,

Compassion in World Farming (2013). The life of broiler chicken. From https://www.ciwf.org.uk/media/5235306/The-life-ofBroiler-chickens.pdf [Accessed on 26/8/2021]

Dayo, P., Ephraim, N., John, P. \& Omobowale, A.O. (2009)..Constraints to Increasing Agricultural Productivity in Nigeria: A Review Nigeria Strategy Support Program (NSSP) Background Paper No. NSSP 006 September 2009.

FAOSTAT. 2018. Food and Agricultural Organization of the United Nations. www.fao.org/faostat/en/\#data/QA_[Accessed: 10. August 2021].

Gornall, A.C., Bardawill, C.J., David, M.M. (1849). Determination of serum protein by means of biuret reaction. Journal of Biological Chemistry. 177(2):751-766

Gupta, N., Mittal, M., Parashar, P., Mehra, V., Khatri, M..(2014). Antibacterial Potential of Elletaria cardamomum, Syzygium aromaticum and Piper nigrum, their synergistic effects and phytochemical determination. Journal of Pharmaceutical Research 8(8): 112-121

Leopold, J., Gerhard, B.,,Ivanka, S., Albena S.,,Albert K. and Erich S. (2006). Journal of Agric. Food Chemistry. 54(17)6303-6307

Makun, H.J. (2018).. Dairy production systems in Nigeria. Presentation delivered at the Technical meeting of Africa Sustainable Livestock 2050, April 2018, Abuja.

Mansoub, N.H. (2011). Comparative effects of using garlic as probiotic on performance and serum composition of broiler chickens. Annals of Biological Research 2: 486-490

Monika, M., Gupta, N., Palak P., Mehra, V. (2014). Phytochemical Evaluation and Pharmacological activity of Syzygium aromaticum: Acomprehensive review. Journal of Pharmacy and Pharmaceutical Science 6(8): 67-72

Muhammad A., Idris, S. I. (2019). Phytochemical Screening and Proximate Analysis of Garlic (Allium sativum) Achives of Organic and Inorganic Chemical Science 4(11):24-32

National Bureau of Statistics (2010). The Review of the Nigerian Economy. Retrieved on 07/06/21 from www.nigerianstat.gov.ng

Neilsen, P.V., Rios, R. (2000). Inhibition of fungal growth on bread by volatile components from spices and herbs, and the possible application in active packaging, with special 
emphasis on mustard essential oil. International Journal of Food Microbiology 60: 219229

NIPOST: Post Offices with map of LGA (2009). Archived from the original on 7 October, 2009. Retrieved 6 June 2021.

NRC., 1994. Nutrient Requirements of Poultry. 9th Edn., National Academy Press, Washington, DC., USA., ISBN-13:9780309048927, Pages: 155

Nwadiaro, P.O. Ogbonna, A.I. Wuyep, P.A. and Sila-Gyang, M.D. (2015): Antifungal Activity of Cucumis metuliferus E.Mey. ex Naudin on Some Post-harvest Decay Fungi of String beans Journal of Academia and Industrial Research (JAIR) 3(10) 342-351

Ogbu, R.J., Abu, A.H., Eustace, B.B., Ochalefu, D.O. (2011). Safety evaluation of hydroalcoholic extract of Cochlospermum planchonii rhizome in rats. African Journal of Biotechnology 10(66): 15006-10.

Okwu, D.E.(2001). Evaluation of the chemical composition of indigenous spices flavouring agents. Global Journal of. Pure and Applied. Science. 7(3). 455-459.

Oluwatosin, K. S., Bashir L., Blessing, U. A., Muhammad, H. G., Niwoye, A. A., Bonghan, B. E. (2015). Alteration in biochemical indices following chronic administration of methanolic extract of Nigeria bee propolis in Wistar rats Asian Pacific Journal of Tropical Diseases 5(8): 23-31

Puvača, N., Kostadinović, L.., Ljubojević, D., Lukač, D., Lević, J., Popović, S., Novakov, N., Vidović, B. And Đuragić, O. (2015). Effect of garlic, black pepper and hot red pepper on productive performances and blood lipid profile of broiler chickens. European Poultry Science 79: 1-13. DOI: 10.1399/eps.2015.73

Puvača, N., Stanaćev, V., Glamočić, D., Lević, J., Perić, L., Stanaćev, V. And Milić, D. (2013). Beneficial effects of phytoadditives in broiler nutrition. World's Poultry Science Journal 69: 27-34

Rahmatnejad, E, Roshanfekr, H.. (2009). Evaluation the effect of several non-antibiotic additives on growth performance of broiler chickens. Journal of Animal and Veterinary Advances 8: 1757-1760.

Reitman, S., Frankel, S.A. (1957). Colorimetric method for the determination of serum glutamic oxalacetic and glutamic pyruvic transaminases. American Journal of Clinical Pathology 28: 56-63

Rivlin, R. (2001) Historical perspective on the use of garlic. The Journal of Nutrition 131: 1S-4S

Rodrigo, A,, Roa R.I., Quintero-Fabián, S., Flores-Gutiérrez, E.O., López, R., Grajeda, J.P., Carrera-Quintanar, L., and Ortuño-Sahagún, D..(2015). Immunomodulation and antiinflammatory effects of garlic compounds. Journal of. Immunology Research.: 401630. DOI: 10.1155/2015/401630 PMCID: PMC4417560

Salie, F., Eagles, P.F.K., Leng, H.M.J. (1996). Preliminary antimicrobial screening of four SouthAfrican Asteraceae species. Journal of Ethnopharmacology 52: 27-33

Schäfer, G., Kaschula, C.H. (2014).The immunomodulation and anti-inflammatory effects of garlic organosulfur compounds in cancer chemoprevention. Anticancer Agents in Medicinal Chemistry.;14(2):233-40.

Shobana,, S., Naidu, K.A. (2000). Antioxidant activity of selected Indian spices. Prostaglandins Leukotienes and Essential Fatty Acids 62: 107-110

Siegel, G., Michel, F., Ploch, M., Rodriguez, M., Malmsten, M.. (2004). Inhibition of arteriosclerotic plaque development by garlic. Wien Med Wochenschr.;154(21-22):51522. PMID: 15638070

Simon, O. (2005). Micro-organisms as feed additives-probiotics. Advances in Pork Production 39: $161-167$

Singh, A., Bhat, T.K., Sharma, O.P..( 2011). Clinical biochemistry of hepatotoxicity. Journal of Clinical Toxicol; doi: 10.4172/2161-0495.S4-001. 
Sofowora, E.A. (1982).. Medicinal plants and traditional medicine in Africa. John Wiley and sons Ltd, New York; 256-257.

Stanaćev, V., Milošević, N., Plavša, N., Bjedov, S., Stanaćev, V., Puvača, N. And Arapović, Ž. (2010). Phyto additives (Allium sativum L.) in the diet of fattening chickens. Proceedings of the 14th International Symposium of Feed Technology, Novi Sad, pp. 295-302.

Tietz, N.W. (1995). Clinical guide to laboratory tests. 3rd ed. Philadelphia: WB Saunders Company; p. 286-8.

The Cable News (Cable.ng) The Future of Poultry Production In Nigeria, Published:July 08, 2019, pp 2

Tilli, C.M., Stavast-Kooy, A.J., Vuerstaek, J..D, Thissen. M.R., Krekels, G.A., Ramaekers, F.C., Neumann, H.A..( 2003). The garlic-derived organosulfur component ajoene decreases basal cell carcinoma tumor size by inducing apoptosis. Archive of Dermatology Research. 5(3):117-23.

Trease, G.E. and Evans, W.C.. (2002). Pharmacognosy. 11th ed. Bailliere Tindll., London, pp 22

Usman, J.G., Sodipo, O.A. and Sandabe, U.K. (2014). Phytochemical screening and acute toxicity study of Cucumis metiliferus E. Mey. Ex. Naudin fruit extract in Cockerels. International. Journal of. Phytomedicine. 6: 243-247.

Yakubu, M.T., Musa, I.F. (2012). Liver and kidney functional indices of pregnant rats following the administration of the crude alkaloids from Senna alata (Linn. Roxb) Leaves. Iran Journal of Toxicology 6(16): 615-25. 